\title{
UNKNOWN CHAPTERS IN THE HISTORY OF "VPERED"
}

The period $1870-1880$ represents an important phase in the history of social movements in Russia. Within that decade ideas and groups merged whose influence can be discerned in the events that preceded and those that followed the upheaval of 1917.

Among those groups one of the more interesting was the so-called Lavrists, or Vperedovtzy, named after the publication "Vpered" (Forward), founded and edited by Peter Lavrov (1823-1900) and first published in Zurich, Switzerland, where Volumes I and II were brought out in 1873 and 1874 respectively, and then in London, where Volumes III, IV and V (the last-named not under the editorship of Lavrov) as well as a bimonthly edition of "Vpered" were published during I 874-1877. In addition, the printing office of "Vpered" also produced several books and pamphlets.

"Vpered" never succeeded in building up a numerous following. The political teachings of its editor had remained outside the main stream of revolutionary thought in the 70's, which was dominated by Michael Bakunin. Yet during most of the period of the 70 's "Vpered" had been, so to speak, the address of the Russian revolutionary and socialist movements.

Due partly to the personality of its editor, the author of "Historical Letters" - the gospel of the populists (narodniki) - and partly to the fact that its regularly published issues represented the only available forum for discussion of serious problems, "Vpered" enjoyed a solid reputation among both friends and enemies. Criticized by many opponents, admired by a small circle of adherents, the publication left no one indifferent and was avidly read by all who joined or were merely interested in the numerous groups inside and outside of Russia that struggled against the regime of the omnipotent Tsar.

Scarcely any personalities of importance could be found in these groups who had not been connected with "Vpered" in one way or

1 The transliteration of Russian names follows the rules adopted by the New York Public Library. Only in cases where a name has become familiar under a different spelling is the latter used. 
another. Men like German Lopatin, Nikolai Ogarev, Nikolai Sudzilovski, Piotr Tkachev, Varlaam Cherkezov and Evgeni Zaslavski contributed to the publication although they were not part of its editiorial mainstay. ${ }^{1}$ Marx and Engels followed it closely, and Marx provided Lavrov with valuable information on a number of topics. Ivan Turgenev regularly supported "Vpered" with funds, and Gleb Uspenski had an article published in it. "Vpered" disseminated substantial information on European labor, and especially German labor, and thus prepared the ground for the German Social-Democratic Party's influence in Russia, which became preponderant there twenty to thirty years later.

Some aspects of the history of "Vpered" and its following have remained obscure despite the considerable number of studies on the 70's published before and after the revolution of 1917 . This is true with regard to the program of the publication and its origin in general, and also to the circumstances which led to the resignation of Lavrov as editor-in-chief in 1876 . Fortunately the archives in the possession of the International Institute for Social History (I.I.S.H.) fill to some extent the lacunae in the existing documentation. The documents made use of by this author include papers gathered by Valerian Smirnov (secretary of "Vpered" from I 873-1876 and co-editor of Volume V), preserved by his wife Nadezhda Kolatschewsky and his son Dr. Valerian Kolatschewsky, and turned over by them to the I.I.S.H. in $1936^{2}$, and a collection of manuscripts, letters and printed material covering almost fifty years beginning with the 70's, which just before the outbreak of World War II were rescued by Mrs. Annie Adama van Scheltema, librarian of the I.I.S.H. from its inception through 1953.

The present study will deal only with the program of "Vpered" and begins with testimony on this subject given by its editor himself.

In March, I 872, delegates from Russia approached Lavrov in Paris with a suggestion for the setting up of a Russian periodical. ${ }^{3}$ Lavrov did not know who had sent the delegates and assumed that behind them stood Russian radical publicists (social critics) who because of censorship restrictions could not express their political views in full and who therefore wished to establish a publication abroad which would be smuggled into Russia. With this in mind, Lavrov, in March,

1 Some of them adhered to ideas that conflicted with those of Lavrov.

2 See "Bulletin of the International Institute for Social History," Amsterdam, Vol. I, 1937, pp. 98-102. Parts of the Smirnov collection were lost during I940-I945, but this author had made copious notes from the originals prior to I940.

3 This paragraph is based on "Narodniki-Propagandisty 1873-77 godov" in the "Materialy dlya istorii russkovo revolutzionnovo dvizheniya. X." Published by the "Gruppa starykh narodovoltzev," Geneva, August 1895. 
1872 in Paris, outlined a program for the planned periodical. This was Program No. I. In the autumn of the same year, Lavrov learned that his assumption had been completely erroneous. He journeyed to Zurich, where he met Russian students and political emigrees, and decided to found a periodical in collaboration with partisans of Bakunin which would serve as a mouthpiece of the united Russian revolutionary movement. For this purpose he prepared, late in $\mathrm{I} 87^{2}{ }^{1}$, a second text of a program. This was Program No. 2. When this attempt to collaborate with the Bakunists collapsed, Lavrov formulated a third and final program which became the official one of his publication and appeared in Volume I of "Vpered". This was Program No. 3, probably completed early in 1873 , since by April of that year a mimeographed copy of the final program had been sent by Smirnov to Buturlin ${ }^{2}$ and by Lavrov to Bakunin. ${ }^{3}$

References to the various "Vpered" programs can be found in memoirs written many years after the events by several leaders of the populists: V. N. Figner, S. F. Kovalik, M. P. Sazhin, N. A. Charushin. ${ }^{4}$ They corroborate in general the statement by Lavrov in "NarodnikiPropagandisty", but quote only two versions of the program (corresponding to Programs I and 3 referred to above). It is worth noting that Lavrov himself, in an account made about ten years earlier than the statement in "Narodniki-Propagandisty", also speaks of two "Vpered" programs prepared by him. i.e., Nos. I and 3 according to our classification..$^{5}$ Figner, Kovalik and Charushin state that the "Vpered" program which they saw [No. I-B.S.] was in mimeographed form; Figner and Charushin point out that this program was not a revolutionary but a constitutionalist one, presenting moderate views and recommending to the youth that they first obtain general education and only thereafter start revolutionary activities; Figner adds that the program conceded that even governmental

1 As indicated in letters written by Smirnov to Alexander Buturlin (see Note 6) during the years 1872 and 1873 , the decisive negotiations between Lavrov and the Bakuninists took place in mid-December 1872 . Therefore the second version of the program must have been written some time earlier, but not before the fall of that year, when Lavrov learned that his first program had been written under a wrong assumption.

2 Alexander Buturlin, a Moscow acquaintance of Smirnov, lived at that time in Montreux, Switzerland. He became a member of the group of supporters of "Vpered."

${ }^{3}$ Undated letter of Lavrov to Bakunin, written shortly after an incident between Smirnov and Nikolai Sokolov in April 1873 (see N.G. Kulyabko-Koretzki, "Iz Davnikh Let," Moscow, I931, pp. 60-72). This letter has been preserved in the archives of the I.I.S.H. 4 V. Figner, "Polnoe Sobranie Sochinenii," Vol. V, Moscow, 1929. S. F. Kovalik, "Revolutzionnoe Dvizhenie 70-kh gg i Protzess 193," Moscow 1928. M. P. Sazhin, "Vospominaniya," Moscow, I 25 . N. A. Charushin, "O Daliokom Proshlom," Moscow, I926.

5 See P. L. Lavrov, "Izbrannye Sochineniya," Vol. I, p. 83, Moscow, 9934. 
officials, such as public prosecutors and investigating judges, could be useful to the cause of the people.

Not only memoirs but also letters of contemporaries refer to the different programs of "Vpered". In January I 873, Smirnov informed Buturlin that authors who were preparing articles for publication in Volume I of "Vpered" had asked Lavrov "to shorten in the program [No. I - B.S.] the part dealing with lawful means and to enlarge as far as possible the statement on revolutionary struggle. P. L. [Lavrov B.S.], needless to say, will be glad to meet this request". Toward the end of that year, Smirnov, in another letter, tried to convince Buturlin that no discrepancies existed between the two programs of "Vpered" and explained that the first one had been sent by Lavrov to a selected group in Russia only in order to provoke discussion and that it had been mimeographed there against Lavrov's wishes. Smirnov suggests to Buturlin that he raise the question of two programs of "Vpered" in a letter to the editor. He did not, however, insist on execution of this plan. Here again it is worth mentioning that Smirnov refers to two [i.e., Nos. I and 3 of our classification] and not three programs. But two or three, the version finally adopted and published certainly had one or more predecessors which deviated considerably from it and which have remained unknown. The author of the present study is privileged to be able to offer to the readers of this Revien the unknown programs of "Vpered" from the collection in the possession of the I.I.S.H. referred to above.

Among the various papers which were apparently part of the personal archives of Peter Lavrov is a copy-book of standard size with a soft blue cover containing text under the heading "Vpered". The text had been copied by Smirnov and contains changes, deletions and substantial insertions made by Lavrov. The combination of the text copied by Smirnov and the emendations originating with Lavrov results in an almost literal version of the final program of "Vpered" [No. 3] except for inconsequential alterations related mainly to style. The text as copied by Smirnov, without the changes introduced by Lavrov, provides quite different reading, which should be collated with 2 I pages written, on stationery, entirely by Lavrov, also under the heading "Vpered!". These $2 x$ pages [see Appendix] were found in the blue copy-book; they deviate in some unimportant points from the text copied by Smirnov.

A careful analysis of these documents leads to the conclusion that: a. The $2 \mathrm{I}$ pages written on stationery by Lavrov is the program of "Vpered" prepared by him in March 1872 in Paris, sent by him to Russia, and which are referred to by Figner, Kovalik and Charishin in 
their memoirs. Thus, this is Program No. I according to our classification [see Appendix].

$b$. The text in the blue copy-book copied by Sminov is probably the version written by Lavrov late in $\mathrm{I}^{8} 72$ as a basis for the negotiations with the Bakunists [Program No. 2 following our scheme].

c. The same text, including changes made by Lavrov, is the finally adopted and only known program. Thus, No. 3 according to our scheme.

Let us now compare the basic version [No. I] with the final version [No. 3]. The first I I pages and the last three of the latter, as printed in Volume I of "Vpered", correspond to the respective passages of the basic version: many paragraphs are literally the same; here and there the emphasis is shifted but in principle there is no difference between these parts of the two documents. Pages 12 to 23 of the program published in Volume I, however, are completely at variance with the basic version [No. I]. They represent a revision of the earlier text. To illustrate the difference we shall quote a number of the most striking passages from the basic version [see Appendix] which were replaced by Lavrov with pages 12 to 23 of the final program [No. 3], as may be seen from Volume I of "Vpered".

"We do not call on the Russian people to take revenge for a thousand years of exploitation; we do not aspire at a new and successful repetition of Pugachev's revolution; on the contrary, we are the first to preach a reconciliation with the past provided that this past is ready to move in the direction of a better future. But we consider it unlikely that such concessions could be accorded voluntarily and will go far enough."

"We address ourselves to the trained part of our educated minority who realize that the future belongs to the plain people, that the exploitation of the latter cannot last eternally, that the moment cannot be avoided when the masses will start the fight against the exploiters, that under such circumstances we have to expect a series of revolts of the Pugachev type, first unsuccessful and then successful. These revolts will destroy the weak seeds of civilization in our fatherland. To forestall such a calamity the trained part of the educated minority should join the plain people, adding the traditions of European civilization to the demands for emancipation of the majority, restraining the bloody explosion of the future by their participation in the events." 1

1 The original is carelessly written. 
"The grounds for lawful activity in Russia are narrow but they do exist. Local administrators, both those in high echelons and in more modest positions, can substantially improve the material conditions of the people and can contribute toward their education. Members of the Zemstvo [a form of local autonomous government in Russia], members of the courts, lawyers are able, in the framework of the existing laws, to contribute towards expansion of the independence of the peasants, towards strengthening of their rights and even toward their political education."

"We call on our fellow sympathizers to be active in behalf of the majority within the framework of the existing laws and to struggle against injustice by lawful means."

"If and when the use of lawful means is blocked, it will not be our fault that we will have to recommend to our friends the means of direct and armed struggle."

"We consider immaterial the form of the state: hereditary or elected monarchy with limited power, a centralized all-Russian republic or several federations more or less independent of one another - we bear no enmity toward any of these forms as such. The purely outer forms of a state present remote and formal questions. The protection of the individual; freedom of thought, word and association; autonomy of communities; preponderance of the interests of the peasants above those of all other groups these are the real issues which should occupy top place in a program of a party aspiring toward the welfare of the Russian people ..."

Lack of space prevents the inclusion in the Appendix of the text of the program copied by Sminov contained in the blue-covered copy-book [No. 2]. We wish nevertheless to point out that this text differs from the basic program written on stationery by Lavrov [No. $\mathrm{I}]$ in the following points:

a. Program No. 2 underscores the common aims of the Marxist and Bakuninist caucuses within the First International and calls upon the partisans of both groups to act in concert.

b. The author of Program No. 2 does not want to be identified with those who believe in the possibility of lawful activities in Russia, although he accepts their cooperation as one of the groups supporting "Vpered". 
This permits the conclusion that the copy-book version of the program was offered to the Bakuninists as a basis for their participation in the planned publication which was later to become "Vpered" Unfortunately it is hardly possible to verify this assumption since the negotiations with the Bakuniststs never went beyond discussion about the membership of the editorial board of the planned publication and collapsed when Lavrov refused to share the editorship with anyone else. It may be that our assumption is wrong, in which case the copy-book text presents an improved version of the $2 \mathrm{I}$-page text written by Lavrov on stationery; the latter could also be considered, then, as only a draft of the first program, the adopted version of which was copied by Smirnov for general use. Be that as it may, the copy-book text and the $2 \mathrm{I}$-page stationery text are basically identical documents.

It is not difficult now to understand why Lavrov never cared to publish his first program or programs of "Vpered". Under the conditions which had developed in the 70's on the Russian political scene, statements admitting the possibility of socialist action by lawful means ["a struggle on legal grounds," as they used to say in Russia] or ignoring the importance of a fight against the monarchical regime would have aroused bewilderment, protest and even suspicion among Lavrov's closest friends.

In the beginning of the decade $1870-1880$ there prevailed another mood. Lavrov knew well the group for whom he prepared his first program, which may therefore be accepted as a true reflection of the political ideas cherished by an articulate segment of the Russian opposition of that time. But the radical publicists, deprived of their leadership after the deportation of Chernyshevski and the death of Dobrolyubov, were not the only group that did not aim at revolution in the beginning of the 70 's.

Many populists who "went unto the people," i.e., settled among the peasants in the villages or among the industrial workers in the suburbs of the large cities, wished, in the first place, to spread knowledge and education. They called themselves peaceful propagandists. Of the two chief male characters in the well-known novel by Turgenev, "Nov", Solomin and Nezhdanov, the first probably expressed more typically the dominant outlook of the leaders of the Russian opposition at the beginning of the 70's. Soon, however, the Solomins had to step down. Under the blows of persecutions the "peaceful propagandists" renounced cultural endeavors and turned to bombs. It is with the organization of these active revolutionists, who on March I [I3], I88I succeeded in assassinating Alexander II, that Lavrov had been associated for many years after $1882-1883$. 
Later he played a leading role in the groups which emerged from "Narodnaya Volya" and developed into the Socialist-Revolutionary Party.

But did Lavrov himself share the theory of political evolution as reflected to a certain extent in his first program for "Vpered"? Again we let him explain his attitude:

In "Narodniki-Propagandisty", referred to above, published five years before his death, Lavrov wrote:

"I have been denounced because of the three different programs of 'Vpered'. These denunciations would be justified only if in these programs, in all three instances, I had aimed at the same goal. But this was not so. The first program had to be a statement for a publication originating from the Russian radical publicists of the 60's appearing as a fighting group in the field of illegal literature in 1872 : the personal opinion of the editor played only a secondary role. The second program was intended for a publication which though deviating in many respects from the Bakuninism of 1872 nevetheless wanted as a matter of principle to preserve unity in the Russian social-revolutionary movement: it reflected the personal views of the editor only to the extent that it did not harm this unity. Only the third program was entirely the program of the editor, who took upon himself, completely and exclusively, to accept some and to refuse other contributions for the publication."

This confession sounds plausible. From the outset Lavrov did not believe that the government of the Tsar would tolerate peaceful propaganda of the socialists and would suffer their attempts to transform the zemstvo or other organizations into strongholds of the peasants. This may be seen from the first program, which appears in the Appendix of this article, e.g., a paragraph crossed out but preserved in the text reads: "But hardly much can be achieved by this means [i.e., lawful means - B.S.]. It is hardly possible to avoid the inevitable evil - the revolution - in order to attain ..."

And yet Lavrov agreed to write a program and head a publication in which he would have had to give space to views alien to his own. To understand his attitude one must realize that differentiation as between the various groups of the Russian opposition and the emergence of hostile trends fighting each other was just at the starting point in 1872 . Solomin and Neszhdanov in the Turgenev novel are united not only because both are in love with Marianna; they belong to the same, so to speak, brotherhood of the Russian intelligentsia. 
Lavrov was flattered at being asked to take over a publication of a group known to him from his years in Petersburg. He was ready to suppress his misgivings about the political philosophy of the Russian radical publicists because the publication in question had to be, as he saw it, a socialist publication. Indeed, all the drafts of the "Vpered" programs - Nos. I, 2 and 3 - professed a socialist credo and declared allegiance to the First International. Most important to Lavrov was the socialist propaganda which "Vpered" would spread throughout Russia, for he was primarily an enlightener and socialist thinker.

Nevertheless Lavrov was not at ease about the different programs he had prepared for his "Vpered". It is certain that he had in his possession all the texts, but refrained from publishing them even in "Narodniki-Propagandisty", his historical study of social movements in the 70's. This was because in founding "Vpered" he became a political leader, spokesman of a party, and in this capacity he could not afford to provide ammunition to the enemies of his faction by publishing all the programs of "Vpered". Had he been a political leader only, he would probably never have written different programs for "Vpered". But this venerated teacher and guide of fearless seekers of truth was drafted to head political movements. The conflict between this role and his true calling sheds some light on more than one chapter in the history of "Vpered".

\section{ВПЕРЕД ! 1 \\ НЕПЕРИОДИЧЕСКИЙ СБОРНИК}

Приступая к изданию на русском языке за гранишею, мы очень хорошо знаем все неудобства подобного издания и все опасности, которые ему угрожают.

Весьма возможно, что читатель взглянет на него с недоверием: что оно может сказать нового и интересного? Для вопрсов обших сушествует иностранная периодическая литература; для вопросов русских надо следить близко за русскою жизнию, понимать ясно, что нужно России, что для нее возможно. Вероятно ли, чтобы

1 Печатаемый текст представляет собой точное воспроизведение рукописи ПІ. $\lambda$. Ааврова. Лишь старая орфография заменена новой. Слова, подчеркнутые в оригинале, выделены курсивом. Текст в квадратных скобках принадлежит мне, кроме случаев оговоренных особо.

Б.C. 
русское заграничное издание могло сказать что либо, непохожее на то, что повторяется сто раз и полнее и лучше изданиями на иностранных языках? Возможно ли ему не только разбирать, но даже понимать, русские вопросы так, как должно [должны] и так как могут делать это журналы, издаваемые в России?

Если әто издание рассчитывает только на свободу слова, несуществуюшую в России, то не будет ли оно бить исключительно на резкость выражения, на скандал ругательства в отношении к лиџам и ко предметам, которых едва можно касаться с почтительною оговоркою в пределах Русской империи? Не будет ли оно призывать молодежь на новые бесполезные жертвы? Не будет ли волновать умы стремлением к неосушествимым целям? Не будет ли оно эфФектною оболочкою малозначительного содержания?

На эти опасения и вопросы мы отвечаем нашею программою, от которой не думаем отступать.

Точные факты - вот основание, на которое мы намерены опираться. Безусловная критика-вот орудие, которое мы намерены употреблять. Борьба с монополиею во всех ее видах в пользу труда - вот обшественная џель, которую мы себе ставим.

Факты для русской жизни будут собираемы в главных џентрах этой жизни, и будут [одно слово неразборчиво] людьми, имеющими возможность следить близко за ее проџессом. Факты заграничной жизни войдут в нашу программу лишь настолько, насколько они будут касаться или развития русского общества, или борьбы против монополии во всех ее видах, которая составляет, по нашему мнению, прямую обязанность публиџистики нашего времени. Как факты заграничной жизни, так и общие вопросы будут разобраны лиџами, подвергавшими их серьезному изучению.

Не фразы, не нападения на личности должен ожидать читатель в новом издании, а критику оснований современного общественного строя. Аичности суть то, что из них выработали обстоятельства; один император может быть несколько лучше или несколько хуже другого; один министр может несколько вреднее действовать на страну, чем другой, и нельзя не указать на вредное влгяние того или другого образа действий; но в сушности, вредны не личности, а их безответственность, их 
исключительнос положение, которое привело их по необходимости к тому или другому роду действий; в ином обџественном строе, они могли бы быть безвредны или даже полезны. По этому мы решительно отказываемся помещать на наших странипах личные ругательства или анекдоты из частной жизни, не имеюшие отношения к общественным вопросам, которые мы имеем в виду. Если деятельность той или другой личности вредна, то она заслуживает публичного осуждения именно в той мере в какой она вредна обществу; если эта вредная личность в частной жизни честна и симпатична, или мелка и позорна, это ни на каплю не изменяет ее вреда для обшества, следовательно и степени ее виновности. Мы судим не частную жизнь а общественное дело, не частных людей а обшественных деятелей. Мы враждуем не против личностей а против обпественных начал, против несправедливости общественного строя.

Самое важное для читателя конечно знать џели, к которым мы стремимся, и не в общих формулах а в частном отношении этих џелей к различным вопросам волнующим современность. Мы по этому войдем здесь в некоторые подробности.

Аля нас в настояшую минуту существуют две обшечеловеские задачи, две борьбы, в которых должен участвовать всякий мыслящий человек, становясь на сторону прогресса или реакции, в которых индифферентным оставаться нельзя, отношение к которым должно определить отношение ко всем остальным вопросам, как второстепенным; две борьбы, которые должны быть девизом всякой личности, всякой партии, всякой наџии желаюшей участвовать в развитии человечества. Әто, во первых, - борьба реального миросозерцания противу миросозерцания богословского, ясного сознания реальных человеческих потребностей противу всех идолов религиозных и метафизических, теоретических и нравственных, короче говоря борьба науки против религии. Это во вторых борьба труда противу праздного пользования благами жизни, борьба полной равноправности противу монополии во всех ее формах и проявлениях, борьба рабочего противу классов, его эксплуатирующих, борьба свободной ассопиации противу обязательной государственности, короче говоря борьба за реализаџию справедливейшего строя общества.

Содействовать этой борьбе есть безусловная, главная цель нашего издания. 
Для этой џели необходима почва, которая опредляет возможнуяо деятельность, необходим выбор средств, которые были бы целесообразны.

Почву составляет современное обшество, так как оно есть, в тех его формах, которые даны, как допускатиие стремление к поставленной выше пели, как враждебные ей или как индифферентные для нее. На первые формы современной жизни мы будем опираться и будем указывать возможность их развития в прогрессивном смысле. К враждебным обшественным формам мы будем относиться безусловно-враждебно. Ко всему тому, что в сушности индифферентно, но, смотря по данным обстоятельствам, может быть прогрессивно или регрессивно, мы будем относиться именно на столько сочувственно или враждебно в частных случаях на сколько оно положительно или отриџательно соприкасается с нашим вопросом. Мы знаем что разом торжество наших пелей осушествиться не может, что для него нужна подготовка, ясное понимание возможного в данную минуту. Именно это возможное мы будем постоянно иметь в виду. В небольших прогрессивных явлениях мы постараемся указать возможность сделать из них почву дальнейшего прогресса. Аля широких џелей будушего мы постараемся указать возможнуго почву в жалком строе настояшего.

Средством для распространения истины не может быть ложь; средством для реализаџии справедливости не может быть ни эксплуатаџия, ни авторитетное господство личности; средством для торжества над праздным наслаждением не может быть насильственный захват незаработанного богатства, переход возможности наслаждения от одной личности к другой. Есть необходимые условия борьбы, при которых приходится употреблять временно противу врагов и ложь, и принуждение, и захват орудий борьбы. Но вне крайней и временной необходимости эти средства вредны для той самой џели, для которой их назнают. Но в кругу единомышленников, товаришей по обџему делу, союзников, ложь есть преступление, преднамеренное распространение иллюзий есть измена делу, принуждение допушено быть не может, әксплуатаџия и личный интерес возмутительны. Люди утверждающие что цель оправдъвает средства должны бы всегда сознавать ограничение своего правила весьма простым трюизмом: кроме тех средств, которые подрыъватот самую цель. Мы 
безусловно отвергаем употребление нецелесообразных средств как в том смысле что эти средства невозможны, так в том, что они, по всей вероятности, принесут более вреда чем пользы, наконеш в том что употребление их вредит пели к которой мы стремимся.

Из предыдушего следует наше отношение к различным вопросам, партиям, обшественным формам и обшественным деятелям современности.

Религиознъй, џерковный, догматический әлемент нам безуслвоно враждебен. Мы опираемся на критику, стремимся к торжеству реальной мысли, к удовлетворению реальных потребностей. Между нами и различными сектами ортодоксальными и еретическими, опираюшимися на откровение или на идеалистическую метафизику нет ничего обџего. Принџип сверхестественного, мистического мы не признаем ни в одном из его оттенков. Союза с сектаторами какого бы то ни было наименования, мы никогда заключать не будем. Всякий лично может верить чему угодно сообразно своему развитию; всякая церковь, всякая ассоџиаџия на основании сверхестественного принџипа, всякое духовенство, служашее посредником между профанами и сверхественным источником истины, есть зло и признано быть не может. [След. Фразы вычеркнуты в рукописи: «Свобода для ассоџиаџии требуюшей в принџипе отрешение от свободы мысли и от свободы действий есть противуречие. Равенство для людей отриџаюџих равенство между верующим и неверушим есть противуречие. Братство в отношении к людям осуждаюшим бо́льшую часть человечества на вечные мучения есть противуречие. Всякою общественною религиозною »] Мы [будем] бороться лишь противу господствуюџих и притеснительных верований, но союз с какими бы то ни было сектами для нас невозможен.

[Две строчки начатого, но неоконченного абазџа - вычеркнуты. Абзаџ этот начинался словами: «Наџиональности сугь...»]

Из предыдушего уже ясно пто сопиальный вопрос есть для нас вопрос первостепенный. Мы видим в нем самую важную задачу настояпего, единственную возможность хучшего будушего. В союзе большинства рабочих в свободную ассоџиапию, в организаџии этого союза для совокупного и могучего действия, в торжестве этой организаџии, и в установлении ею нового 
обшественного строя на развалинах промышленно-легальных государств и сословий настояшего мы видим единственное средство осушествить это будшее. Возможнылм орудием для әтого в настоящую минуту мы считаем лишь Международное общество рабочих, при усилении его организаџии для неминуемой борьбы. По әтому мы примыкаем к его программе; мы не будем спорить даже против пунктов ее, с которыми мы не вполне согласны. Разногласия в свое время раз [яснятся] и раз [решатся]. Теперь надо всеми средствами отстоять начала, на которых зиждется борьба рабочих против эксплуататоров. Надо сплотиться и действовать сообща противу общих врагов. Мы приглашаем всех сочувствуюших примкнуть к әтой организаџии, так как она есть и усиливать ее всеми средствами, даже в том случае, когда тот или другой пункт возбудит несогласие, когда та или другая влиятельная личность в среде ее не будет вполне симпатична тому или другому из наших единомышленников. Другого средства для обшей борьбы пока нет, а это средство возможно, сильно и допускает самое широкое развитие в будушем. Одиночная борьба противу могучей организаџии врагов бессмысленна и неџелесообразна. Личность, стремяшаяся к лучшему будушему, должна ясно сознавать какие средства возможны для ее пелей.

Государства, так как они существуют, враждебны рабочему движению и все они должны окончательно разложиться чтобы дать место новому обшественному строю, где самая широкая свобода личности не будет препятствовать солидарности между равноправными личностями и обширной коопераџии для общей џели. Но это дальнее будушее, обшественный идеал который следует иметь постоянно в виду, не обманывая себя надеждою на возможность его осуществления ни сегодня, ни завтра. Парижская коммуна і87і была первою попыткою осушествить политический строй независимых самодержавных џеентров с политическим преобладанием рабочего сословия, центров связанных свободною федераџиею для общих џелей. Федераџия свободных и самоуправляюшихся мелких џентров еше не есть окончательное осушествление будушего идеала, но она ближе других к нему подходит и мы будем поддерживать эту программу всюду где проявится попытка ее осушествления. Но и әта программа, по видимому, еще дахека от своего осуџествления, 
даже плохо понятна большинству, которое могло бы к ней стремиться. Гораздо уже, но за то гораздо понятнее для большинства и не противуречит нашему идеалу программа Соединенных штатов Европы с политическою конституииею Северно-Американских Штатов. Мы будем поддерживать и все политические стремления которые имеют в виду эту, довольно ограниченную, программу. Но на этом мы останавливаемся. Все стояџее ниже федераџии Северо Американского штата, все политические партии с их разнообразными конституџионными идеалами более или менее либерального свойства, всякая попытка заменить петтрализованную и буржуазную империю столь же џентрализованною и буржуазною республикою, заменить сушествующее распределение территории другим распределением с другими џентрами и другими законами - это для нас индифферентно; все эти явления суть явления [ г сл. неразб.] которые могут быть хороши или дурны смотря по тому, обещают ли они Международному союзу рабочих и принџипам им поставленным, более или менее широкое влияние. Так как свобода мысли и слова, свобода ассоџиаџии, участие низших классов в управлении, расширение обучения безусловно помогаго этим принџипам, то мы их будем поддерживать всюду, кто бы ни был их проводником, но мы посоветуем нашим единомышленникам поддерживать эти политические программы и пользоваться ими не вступая в союз о либеральными партиями, которые их проводят. Мы с ними можем сходиться в некоторьх пунктах. Наши пели безусловно различны. В государствах, где рабочее сословие (крестьянское или фабричное) может захватить в свои руки политическое влияние, едва ли не полезнее ему воспользоваться сушествующими политическими формами для своего дела птобы потом перестроить общество путем прямого законодательства. Там где эго невозможно, ему остается неизбежно путь революџий, но надо помнить что революџии всегда лишь неизбежное зло, что они всегда весьма тяжело ложатся именно на большинство, что реакџии, за ними следуюшие, в случае неудачи, составляют самый бедственный период общественной истории и что, предпринявши путь революџии, надо организовать победу. В противном случае лучше обождать. Революшии вызвать нельзя и не должно; можно и следует лишь воспользоваться 
для них существуюшими историческими обстоятельствами.

Наџиональности представляют соверценно реальную и неизбежную почву вслкого действия. Приходится действовать в данной местности, на обшество говоряшее даниым языком, выработавшееся до данной культуры. Если это не взять в соображение, то абстрактная шель никогда не осушествится. В разньх местностях для разных наџиональностей задачи данного мгновения могут быть различны. Каждая должна делать свое дело, сходясь в обџем стремлении к обџечеловеческим џелям. Борьба против религиозного злемента, отриџание всякого союза с џерковыю или сектаторскою организаџиею, распространение организации Интернационала, стремление к федерации свободных самоуправляющихся общин или к организаџии Соединенньх Штатов Европы - в этом все напиональности могут и должны работать сообџа, и этой общей работе нет препятствий. Для нее граниџ, языков, преданий не суџествует. Есть только люди и общие им всем џели. Эти принџипы неизбежно требуют самую решительную борьбу противу той наџиональной раздельности, противуположности, враждебности, которые еше слишком часто отзываются в привычкак даже мысляших личностей.

Ниже этого вопроса различны и местны [ниже этого - вопросы различные и местные]. Аичное сочувствие может поставить шведа в ряды французов противу пруссаков, но это дело личное, как религиозное убеждение. Аля шведов вообще спор Франуии как целого противу Германии как целого, индифферентен, потому что торжество того или другого прави [тельства] не разрешает ни религиозного, ни соџиального вопроса, не подвинет на осушествление европейских соединенных штатов и даже не расширит свободы слова и ассоџиаџий. В частных вопросах у Шведа есть свои частные задачи, которые требуют всей его мысли, всей его деятельности.

Так и для русского. Вне обшечеловеческих задач, упомянутых выне, в зависимости от них, как их второстепенное проявление или как средство для их будушего разрешения, русские имеют свои задачи и мы теперь перейдем к ним.

Для русского спеџиальная почва на которой может развиться будушее болышинства русского населения, в том смысле, который обозначен общими задачами, есть крестьянство с общинным 
землевладением. Развить нашу обџину в смысле обџинной обработки земли и обшинного пользования продуктами; сделать из мировой сходки основной политический элемент общественного строя; поглотить в обџинной собственности частную собственность соседних землевладельџев; дать крестьянству то образование без которого оно никогда не сумеет воспользоваться своими легальными правами, как бы они широки ни были, и никогда не выйдет из под эксплуатаџии меньшинства даже в случае самого удачного социального переворота - вот спеуиальные џели которым должен содействовать русский желаюоший прогресса своему отечеству.

Мы вовсе не желаем нашему народу правовых революџий, тяжелых потрясений. Если можно достичь џелей, которые мы поставили, путем мирных и легальных реформ, путем постепенного развития и уступок со стороны господствуюшик элементов правительства, частного землевладения и промышленного капитала, - тем лучше. Чем менее страданий, чем менее жертв требует история, тем легче большинству, которое всегда приносит всего более жертв и терпит всего более страданий. Мы не призываем русского народа $к$ мшению за тысячелетнюю әксплуатаџию, не желаем новой удачной Пугачевшины; напротив мы первые готовы проповедывать примирение с прошедшим если это прошедшее готово уступить лучшему будушему. Но мы считаем крайне невероятным чтобы подобные уступки совершились добровольно в достаточно широких размерах; история не представляет никогда ничего подобного, и потому, желая мирного разрешения вопросов, мы все таки говорим читателю: если оно невозможно, то готовьтесь к борьбе, как бы она тяжела ни была, скольких бы жертв она ни стоила; готовьте к ней народ русский, так как может случиться что ему предстоит лишь силою завоевать свое будущее; а оно должно быть завоевано.

При низком образовании большинства, при малой его грамотности, мы не имеем возможности прямо обрашаться к большинству с нашим словом. Мы обрашаемся с ним к той развитой доле нашего образованного меньшинства, которая понимает что будушее принадлежит народу, что эксплуатаџия его вечною быть не может, что неизбежно придет минута когда он захочет избавиться от своих эксплуататоров, что в таком положении 
дел приходится ожидать ряд пугачевщин, сначала неудачных, но которые наконеш удадутся и унесут тогда с собою те бедные әлементы обшечеловеческой џивилизаџии которые развились в нашем отечестве; что для предотврашения этого бедствия, необходимо [разви́той] доле образованного меньшинства стать в ряды народа, соединяя традиџию европейской џивилизаџии с требованием әмансипаџии большинства, умеряя кровавый взрыв будушего своим участием. Мы обрашаемся к тем, которые ставят благо обшее выше личньгх мгновенных выгод, справедливость в отношении к ряду страждуших поколений выше монополии наслаждения результатами европейской культуры в малочисленном классе состоятельных личностей. Мы обрашаемся к людям, которые решились употребить умственное развитие им доступное не для себя только а для большинства людей.

Мы призываем их, кроме общечеловеческих задач, указанных выше, к работе на пользу народу в пределах России.

Мы уже говорили что не призываем к революуионным мерам и что революџии не создаются личностями. Что можно сделать путем маленьких реформ то и следует сделать. Как ни мала легальная почва в России но она сушествует. Местный администратор, как крупный так и мелкий, может легальнызм путем сделать многое для улучшения материального положения народа и для способствования его умственному развитию. Член земства, член суда, адвокат может способствовать на легальной почве расширению самостоятельности, укреплению прав, даже политическому воспитанию крестьянства. Под тяжким ярмом явной и негласной џензуры писатель, редактор журнала, издатель могут все таки легально провести в круг читателей кое какие верные оџенки фактов, более широкое понимание обшественной жизни, могут бороться в более или менее широких пределах за научное воззрение противу богословских призраков, за более справедливый строй обшества против настояџего зла. Мы призываем наших единомышленников изучить самым тшательным образом все мелочи положительного закона, на которых можно огереться для легальной борьбы за лучшее будушее; мы постараемся сами способствовать изучению этой легальной почвы будушего. Изучив ее, следует ею пользоваться на сколько это можно. Не беда, если произвол администраџии и исключительные меры будут направлены противу людей стояших на 
легальной почве; они обязаны ее отстаивать всеми силами даже при полном убеждении в неизбежности поражения; во первьх иногда в частном случае удастся отстоять ее, а это уже победа; во вторых надо выяснить всем, кто интересуется русскою жизнию, что мы, борџы за будущее, не отвергаем законности потому лишь что она есть законность, что мы готовы всегда верить искренности законодателя, вписавшего в свод пункт благоприятный для будушего, что нашим противникам, чтобы подавить нас, приходится становиться на почву произвола и исключительных мер, отридать свою пресловутую любовь к легальности и уклоняться от начал ими самими торжественно вписанных в законы их государственного строя. Мы призываем и будем призывать наших единомышленников к общественной деятельности на легальной почве в пользу большинства, к борьбе противу несправедливости на легальных основаниях.

[Следует начало нового абзаџа, зачеркнутого в рукописи: «Но едва ли можно сделать много этим путем. Едва ли можно обойти неизбежное зло - революџию для достижения...»]

Но легальная почва может сделаться и пире в данную минуту. В самодержавных государствах, где правительство безответственно по закону, оно тем более ответственно пред мнением обшества в минуту общественного бедствия или государственной неудачи, или явых ошибок и злоупотреблений управления. Бывали и были в истории русской последнего времени минуты, когда легальная недоступность правительства для обшественного суда становилась иллюзиею, когда суд этот совершался в явном пориџании, в потаенной литературе, в ослаблении карательных мер над общественною самодеятельностью. Не имея вовсе в виду личных нападок, мы должны однако прямо признать, тто группа личностей руководящих делами Петербургской Империи, вовсе не представляет ручательства умственного и нравственного чтобы подобные минуты ослабления давящей правительствснной власти не могли наступить по тому или другому случаю в довольно скором времени. Тогда политическая партия наиболее ясно определившая свою программу, опирающаяся на более значительные умственные силы, умевшая приобрести более влияния на население, внушить ему более доверия будет в наиболее выгодном положении для осушествления значительной части своей программы. 
Допустим наступление такой минуты и спросим себя, какие партии у нас могут выступить для борьбы.

Это во первых партия консерваторов неограниченной монархии и административного всевластия, партия стояшая во главе управления, бороться с которою в обычное время невозможно, но мы именно допустили мгновение ослабления этой џентральной всемогущей, подавляюшей партии, ее расстройство, ее междуусобную борьбу вследствие дворџовых и личных интриг, следовательно считаем ее влияние нейтрализованньм.

Это во вторых конституџионная либеральная партия по сушествуюшему европейскому образџу, которая представляет неособенно обширную, но вовсе не однородную группу людей с положением и капиталом, с именем в прессе, с влиянием в земстве, с административною опытностью. Они имеют будуџее и вероятно попытаются играть и будут играть видную роль при первом случае, который вызовет общественное мнение и общественную деятельность. Они будут за конституџионную монархию, более или менее либеральную, за свободу слова, за самоуправление; но они вероятно раздроблтся на оттенки по вопросу о свободе ассопиаџий, из страха к соџиализму; по вопросу об џентрализаџии и деџентрахизаџии; по вопросу об участии большинства населения в политической жизни; по вопросу о влиянии капитала и образования на государственный строй. Именно потому, что они живут европейской либеральной традиџией, они вносят в споры о русской государсвенной конституџии все колебания европейских либералов. Кроме того у пих нет в России той почвы политической традиџии обширного сословия буржуазй, которая их поддерживает на западе. Наше чиновничество и нашй помешики не составляют органического общественнного џелого и, при отсутствии политической традиџии, не могут быть прочною опорою ни какой партии. По этому эта партия кажется влиятельной лишь по отсутствии видимых противников с определенной программог. Сильные в борьбе противу подавляюшего самодержавия и административного произвола - и на столько наши союзники они будут слабы в сушественных вопросах, для которых у них не может быть обшей программы; они восторжествуют лишь в том случае, если против них не станет партия с более определенной программой и если они беспрепятственно поведут за 
собою меньшинство, считаюшее себя образованным, но не имеющее никаких политических идей, поведут не встречая препятствий в крестьянском большинстве.

В третьих есть партия, считающая себя народною, по видимому сочувствуюшая большинству, готовая ему помогать и стать в его ряды, но усвоившая лишь формы народной культуры и не способная понять обшечеловеческих идей, которые одни могут повести к лучшему будуше[му] русский народ и сделать его участником обшечеловеческого прогресса. Это так назьваемые славянофилы, для которых мумия русского православия и безнравственность русской патриархальной семьи составляют сушность русской народности. Они малочисленны, мало даровиты и в настоящую минуту кажутся бессильными, но әто может быть вовсе обманчиво в минуту обшественного потрясения. Их сила в народном невежестве; неразвитой массе весьма извинительно связывать свои идеалы лучшего будушего с привычными формами своей культуры и в данную минуту весьма возможно, в случае столкновения европейско-конституџионной партии с партией опирающейся на патриархальность и на православие, что за последней станут массы народа, не сознающие, что его предводители готовят ему отречение от всякого человеческого будушего. Внезапное влияние этой партии, влияние неминуемо вредное, может быть парализовано лишь противупоставлением ей другой партии, еше жарче принимаюшей к сердиу интересы масс и состояшей из личностей, которые сумели бы внушить к себе доверие народным кружкам, с которыми [они] находились в соприкосновении. Некоторое пособие к борьбе противу этой славянофильской партии можно найти в том обстоятельстве, что православное духовенство, увеличение политического значения которого составляет неизбежный элемент славянофильской прораммы, сумело, в продолжении почти тысячелетнего соприкосновения своего с массою народа, скорее внушить ему, в большинстве случаев, презрение к себе чем приобрести на него какое либо влияние. С другой стороны личности, которые ныне стоят во главе деятельности славянофилов, позволяют думать что эти деятели скорее примкнут к европейско-либеральной конститушии с ограждением господства православия (что наши европейские либералы охотно уступят) чем решатся стать во главе народного движения. 
Против этих то партий, которые будут в минуту потрясения обшества, оспаривать друг у друга влияние, следует образовать новуюпартию,котораяимелабылегальнымпутемвземствеивуправлении своих приверженџев, с ясно определенною программою: преобладание крестьянского әлемента в государственном строе при подчинении всех прочих государственных вопросов вопросу об улучшении их материального благосостояния и их умственного развития на почве вполне светской; перенесение возможно более политической жизни в мелкие обџинные џентры; усиление в строе обшины коллектиьного элемента пред индивидуальным и патриархальным. Эта политическая программа не составляет вовсе утопии, может быть поставлена при первом удобном случае совершенно определенно, составляет почву, допускаюшую дальнейшее прогрессивное развитие именно в том смысле, который указан выше, и для каждой губернии, для каждого уезда, для каждой волости может быть выработана в частностях в пределах возможного, при чем в иных местностях обшина может быть рассматриваема как равнозначушая с волостью, в других как отличная от нее. Всюду программа может быть ясна для крестьянства как усиление значения мира и устранение влияния попа, как усиление представителей мира и его интересов в уезде, в губернии, наконеџ в обшей земской думе, когда настанет возможность ее собрания. Самоуправление общины и светская наука - вот простые начала, которые должны быть девизом новой партии. Они согласны с требованием полного ограждения личности, полной свободы слова, полной свободы ассоџиаџии, выборов всего уездного, губернского и государственного управления земством, - все пункты в которых партия светской обшины может встретить частных союзников в других партиях, не сливаясь с ними, так как ее џели не суть их џели и лишь в некоторьх пунктах она с ними согласна. К образованию этой политической партии полноправной общины со светским развитием мы приглашаем сочувствуюших нам читателей как к ближайшей спеџиалњной џели настояшего, џели которая далеко не осушествляет вполне истинного обшественного идеала, но лежит по дороге к нему, и может служить почвою для дальнейших политических и сопиальных завоеваний.

Мы постараемся уяснить возможность организаџии әтой партии и частных условий ее развития для разных местностей, на 
сколько можно на легальной почве настояшего, или на легальной почве будущего, в случае потрясения, которое дозволило бы ей заявить свою программу открыто и выступить на почву политической деятельности. Но для того чтобы это [было] возможно надо подготовлять ее сплочение всеми силами, чтобы минута действия не застала нас в расплох и мы не оказались бы расстроенными пред организованным врагом.

Именно чтобы эта легальная деятельность была возможна необходимо чтобы люди, сочувствующие нашей программе, не устранялись от общественной деятельности административной или выборной, делали столько добра народу сколько можно, приобретали влияние и внушали к себе доверне чтобы в данную минуту народ пошел за ними веря их слова[м] и вынес их на положение, где бы они могли принести широкую пользу своею обдуманною программою лучшего обшественного строя.

Но для этого первое и необходимое условие заключается в их собственной подготовке, в уяснении их собственной мысли серьезными научными занятиями, серьезною критикою общественных вопросов, необходимых условий, данной среды, определяющей, что возможно в данную минуту, и желательных улучшений. Строгая холодная критика реального должна сдержать порывыгорячего стремления к лучшему, если это лучшее неосушествимо без предварительной подготовки. Тщательное усвоение всех юридических, экономических, умственных, нравственных, личных особенностей почвы, на которой приходится действовать для них обязательно, если они они тодно хотят действовать а не довольствоваться громкими фразами и пустыми пожеланиями. Дружное действие сообџа, взаимная поддержка, обмен мыслей, снисходительность к личным недостаткам и угловатостям без которых никто не обходится составляет необходимое средство для возможности побед. К этой подготовке мы призываем сочувствующих нам и ей будем содействовать на сколько сумеем.

Но мы не обманываем себя надеждою, что легальный путь для осушествления программы, нами поставленной, поведет к цели. Весьма возможно, даже вероятно, что враги русского народа, его эксплуататоры, поклонники отжив [а]ющих либеральных теорий западной политики сплотятся для противудействия крестьянству стать господствующим классом в политическом строе будущей Руси. Они будут всеми силами теперь противу- 
действовать усилению крестьянского әлемента в земстве, выборам или назначению лиџ известных своим сочувствием крестьянским интересам; а в будущем они соединятся против представителей программы полного обшинного самоуправления и против подчинения интересов всех прочих классов обшества интересу крестьян. Если легальный [путь] будет закрыт, то не наша вина будет, когда придется призвать напих единомышленников на путь прямой, вооруженной борьбы. Так как этот случай возможен и, может быть, вероятен, то наши единомышленники должны готовиться и к нему. Эта подготовка ничем не отличается от той которую мы указали выше для легальной деятельности. Приобретение личного влияния и доверия в народной среде; подготовка себя научным развитием и строгою критикою составляют и здесь сдинственное орудие. Повторяем: революџии не следует вызывать, но если они необходимы, то следует воспользоваться обстоятельствами им способствуюшими.

При әтом формы наследственного или выборного императорства с крайне ограниченною властью, единой всероссийской республики или нескольких федераџий более или менее независимых мы считаем вовсе не важными и не относимся враждебно ни к одной из этих форм независимо от их содержания. Это все далекие, формахьные вопросы. Ограждение личности, свобода мысли и слова, ассоџиаџии; самоуправление обџин, подчинение интересам крестьнства всех прочих интересов, вот насущные вопросы, которые должны скоро выступить на первое место, вопросы которые должны стать во главе программы партии стремяџейся к благу русского народа, и которые мы постараемся уяснить в их частностях.

Это русские вопросы внутренние, но есть и внешние.

Это прежде всего вопрос славянский и относительно его мы ставим совершенно-определенную программу.

Мы верим что славянские народы могут настолько же как народы германские, романские, англо-саксонские быть орудиями для развития соџиальной будушности человечества, в том смысле, который мы указали выше. Мы верим даже что в столкновении славян с немџами в пределах двух немеџких империй, с турками в пределах Оттоманской Порты менее политической рутины, менее буржуазной традиџии находится на стороне славян, что образование вполне независимьх 
славянских тосударств там где теперь суверенная власть принадлежит немшам и туркам, будет шаг вперед к осуществлению сопиальных идеалов человечества; по әтому мы сочувствуем глубоко борьбе всех наших братьев славян против господства обветшалой культуры Турџии или буржуазных политических типов Германии. Но мы сочувствуем этой борьбе лишь на столько, на сколько в ней проявляется стремление за лучшее общечеловеческое будушее, за ограждение личности, за свободу мысли и слова. Живыми партиями в среде славян мы признаем лишь те, которые пишут на своем знамени рядом с девизом независимой наџиональности девиз соџиальной борьбы противу монополии частных собственников и капиталистов, научной борьбы противу религиозного злемента. Для нас бессмыленна и достойна сожаления борьба наџиональности, которая сковывает свои идеалы независимости с мертвыми и вредными идеалами православия или католиџизма, с безнравственными преданиями феодализма, боярства или шляхетства. Соџиальные партии Сербии, Кроаџии, Чехии, Польши суть наши братья по делу и по крови; их омладинам мы с радостью откроем страниџы нашего издания; мы будем рукоплескать их победам; мы надеемся что им и только им удастся восстановить независимость их родины, что они вступят равноправными членами в будуџий строй Соедниенных Штатов Европы. Славянский вопрос имеет для нас значение как одна из отраслей обшечеловеческого вопроса. Мы вполне уверены что все наши единомышленники в России в этом смысле видят свой вопрос в вопросе славянском и хотели бы вместе с нами чтобы вперед!, написанное в заголовке нашего издания, было призывом всех славян к соџиальному возрождению, к господству в их среде труда над монополиею, науки над богословскими иллюзиями, чтобы наше вперед! сделалось органом всеславянским, программою федераџии Славянских соединенньг штатов, органом всех славян, дошедших до сознания что будушее для славянства как для всего человечества заключается в девизе: наука и обџина, истина и труд, война идолам и монополии!

Это разрешает и самый трудный, повидимому для русского вопрос, вопрос польский. Кто поставил интерес хлопов выше интересов шляхты и бьется за идеал Соединенных штатов Европы, тот наш брат и союзник. Еслибы нашим единомышлен- 
никам пришлось говорить во всероссийском земстве о вопросе между Польшей и Россией они предложили бы конечно, чтобы каждая обшина решила самостоятельно, независимо от всей предыдушей истории, хочет ли она быть русской, или польской, или литовской, или малорусской. В будуших Соединенных Штатах Европы граниџы между штатами будут иметь крайне мало значения; при дальнейшем же самодержавии обшин, различие наџиональностей становится бледным преданием истории без политического смысла. Зашитники преобладания шляхты и союзники католиџизма враги наши, потому что они прежде всего враги народа польского.

Отсюда следует и наше отношение $к$ народам иных племен. Мы будем на стороне всех тех кто стоит за один из трех политических идеалов нами поставленньх в начале. Мы будем всюду на стороне партий и народов, стояших за науку против религиозных догматов, за ограждение личности против произвола администраџии, за свободу мысли, слова и ассоџиаџии против стеснительных мер. Мы оставляем в стороне, как чуждые обшечеловеческим џелям и русским интересам все частные и местные вопросы лежашие вне этой области.

Такова наша программа; мы может быть вошли в излишние подробности, но мы желали ясно установить наше отношение ко всем обшечеловеческим вопросам, ко всей русской современности.

И теперь призываем всех сочувствуюпих нашей программе с нами - Вперед!

Издание будет выходить в начале непериодически по мере накопления материала, книжками в го печатных дистов или свыше того.

Џена каждой книжки будет.

Можно подписываться вперед на 4 книжки составляющих том. 